\title{
Red snapper management in the Gulf of Mexico: science- or faith-based?
}

\author{
J. H. Cowan Jr. • C. B. Grimes • W. F. Patterson III • C. J. Walters • \\ A. C. Jones - W. J. Lindberg • D. J. Sheehy $\cdot$ W. E. Pine III - J. E. Powers • \\ M. D. Campbell $\cdot$ K. C. Lindeman $\cdot$ S. L. Diamond - R. Hilborn • \\ H. T. Gibson · K. A. Rose
}

Received: 12 October 2009/ Accepted: 12 March 2010/Published online: 3 April 2010

(C) The Author(s) 2010. This article is published with open access at Springerlink.com

\begin{abstract}
The most controversial fishery in U.S. waters of the Gulf of Mexico (Gulf) is for northern red snapper Lutjanus campechanus, which collapsed in the late 1980s when stock biomass became too low to be fished commercially in the eastern Gulf. Red snapper management began in 1989; the stock is now showing signs of recovery. The Gulf of Mexico
\end{abstract}

Electronic supplementary material The online version of this article (doi:10.1007/s11160-010-9165-7) contains supplementary material, which is available to authorized users.

J. H. Cowan Jr. $(\bowtie) \cdot$ J. E. Powers .

M. D. Campbell · K. A. Rose

Department of Oceanography and Coastal Sciences,

Louisiana State University, Baton Rouge, LA, USA

e-mail: jhcowan@1su.edu

C. B. Grimes

Santa Cruz Laboratories, NOAA Fisheries, Southwest

Fisheries Science Center, Santa Cruz, CA, USA

W. F. Patterson III

Department of Biology, University of West Florida,

Pensacola, FL, USA

C. J. Walters

Fisheries Centre, University of British Columbia,

Vancouver, BC, Canada

A. C. Jones

8950 SW 62nd CT, Miami, FL, USA

W. J. Lindberg · W. E. Pine III

Department of Fisheries and Aquatic Sciences,

University of Florida, Gainesville, FL, USA
Fishery Management Council has been slow to sufficiently reduce catches of the directed fisheries to rebuild the stock in a timely fashion, although compliance with the Magnuson-Stevens Reauthorization Act of 2006 (MSRA) required substantial cuts in the harvest of red snapper beginning in 2007. In our opinion, this could have been avoided if conservative management practices had been adopted earlier. We believe that 'faith-based fisheries' arguments have been used to defer effective management

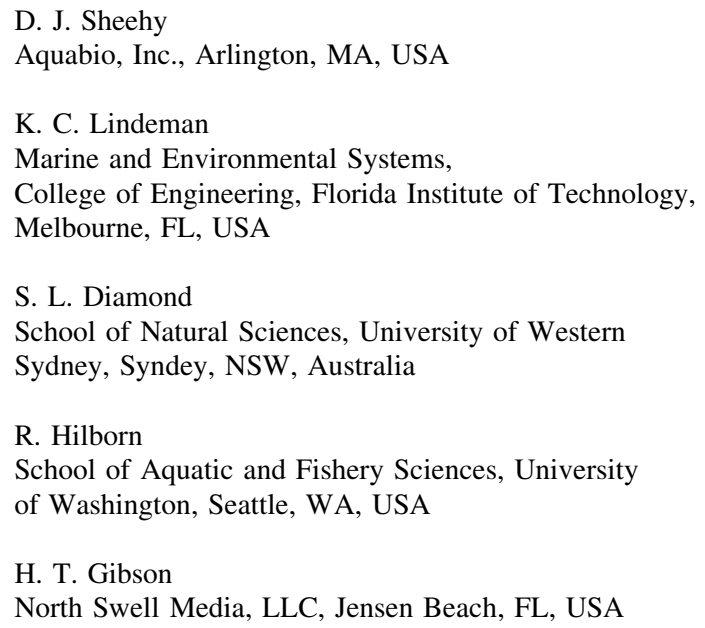


of red snapper in the Gulf, which in turn has strained the relationship between science, management, and stakeholders there. We provide a simple empirical argument and alternate interpretations of a recently published perspective on the historical fishery of red snapper in the Gulf to conclude that the preponderance of evidence used in the agency stock assessment process, and the simple arguments made here, do not support the perspective that the red snapper stock has increased in size sufficiently to defer compliance with the MSRA.

Keywords Red snapper - Faith-based fisheries · Artificial reefs · Overfishing - Historical perspective

\section{Introduction}

The most controversial fishery in U.S. waters of the Gulf of Mexico (Gulf) is for northern red snapper Lutjanus campechanus, which collapsed in the late 1980s when stock biomass became too low to be fished commercially in almost half of the stock's former range. Red snapper management began in earnest in 1989 , yet the stock is only now starting to show signs of recovery. More information about the history of red snapper management is available elsewhere (e.g., Hood et al. 2007), but suffice it to say that conflict among competing stakeholders has made stock recovery and sustainable fishing especially difficult to achieve. Total allowable catch (TAC) has been effectively split between recreational and commercial fisheries since the early 1990s, but until recently much of the fishing mortality was estimated to be attributable to unintentional harvest (bycatch) of juveniles in the Gulf shrimp fishery (Goodyear 1995; Porch 2007). Hence, the Gulf of Mexico Fishery Management Council has been tugged in many directions, and has been slow to sufficiently reduce catches of the directed fisheries to rebuild the stock in a timely fashion. Recently, compliance with the Magnuson-Stevens Reauthorization Act of 2006 (MSRA; US Public Law 94-265) has required substantial cuts in the harvest of red snapper. In our opinion, this could have been avoided if conservative management practices had been adopted earlier.

Like the examples described by Hilborn (2006), a 'faith-based fisheries' argument has been used to defer effective management of red snapper, and consequently has greatly strained the relationships between science, management, and stakeholders in the Gulf. The central issues that have stalled timely management are the beliefs both that bycatch reduction was possible via gear modifications, and that deployment of large numbers of artificial reefs in the northern Gulf transformed and improved habitat for adult red snapper (Shipp 1999), resulting in larger standing stocks, that can support higher catch levels than are currently indicated in red snapper stock assessments. Assessment results supported the first of these beliefs, indicating that reduction of bycatch mortality on juveniles was key to stock recovery, as did initial positive tests of bycatch reduction devices (BRDs) that excluded juvenile red snapper and other finfishes from shrimp trawls. However, observerbased characterization of BRD performance later indicated that gear modifications would not reduce red snapper bycatch sufficiently to ensure a timely recovery of the red snapper stock (NMFS 2004; http://www.sefsc.noaa.gov/sedar/download/SEDAR7_ DW38.pdf?id=DOCUMENT). We address the latter belief-that artificial reef deployment has enhanced production of red snapper in the northern Gulf and should be considered the key component of stock recovery-in this paper.

The belief that mass deployment of artificial reefs, in their various forms, is a panacea for red snapper and other overfished stocks in the northern Gulf is widespread among various fishing constituencies, but the specifics of this argument were elucidated in a management perspective published by Shipp and Bortone (2009). According to these authors, oil and gas platforms that began appearing in the western Gulf in the late 1940s function secondarily as large artificial reefs, and the placement of platforms, as well as a myriad of other artificial reef structures in the northcentral and eastern Gulf since the 1970s, has enhanced production and altered distribution of red snapper biomass (Shipp and Bortone 2009). True, results of the last benchmark stock assessment for red snapper indicate that recruitment and stock productivity may have increased since the late 1980s. However, Porch (2007) listed several possible causes for this putative increase, none of which were considered by Shipp and Bortone (2009) beyond artificial reef deployment. Unfortunately, Shipp and Bortone (2009) provide little information on red snapper life history or ecology, nor do they provide a 
mechanistic explanation for the thesis that artificial reefs have increased red snapper stock-specific productivity, or a concrete rationale why they believe the stock is in fact not overfished (despite numerous stock assessments dating to the 1980s and accompanying extensive peer review that indicate otherwise). In the following sections we provide objective information across multiple topics in support of a science-based argument that does not support the faith-based perspective that artificial reefs are responsible for recent signs that red snapper in the US Gulf are beginning to recover from overexploitation.

We recognize that the stock assessment process for red snapper and other species is controversial and sometimes difficult to understand, so we base our arguments on two simple vital rates; growth and mortality (natural and fishing), and how these two relate in the calculation of biomass production. This is not a review of red snapper stock assessments, and neither of these vital rates are taken from assessments; rather, each is derived empirically. We use this information to address the following key questions: (1) it is possible that artificial reefs primarily attract red snapper to shelter rather than directly producing more fish (the attraction vs. production debate), (2) is it likely that habitat for adults limit red snapper population size?, (3) what is the effect of fishing on red snapper biomass production?, and (4) is there evidence that artificial reefs and oil and gas platforms have increased the carrying capacity for red snapper in the Gulf such that current management practices are too stringent? We provide boxes separate from the text that include procedural details for readers that wish to see them. We also make occasional references to values produced by the most recent red snapper stock assessments (SEDAR 2005; Porch 2007; SEDAR 2009) for comparisons. Our analysis does not address spatial variation in demographic rates due to the intrinsic habitat quality of essential fish habitat or artificial reefs at scales smaller than regional (Alabama, Louisiana and Texas). Instead, it addresses possible habitat effects at the population level at spatial scales relevant to red snapper management.

Nor should the information provided here be perceived as an alternative to the Southeast Data, Assessment, and Review (SEDAR) process and it's outcomes, i.e., this is not a stock assessment. It should also be noted that the authors of this paper agree with agency assessment findings that the red snapper stock is overfished and until recently, perhaps, experiencing overfishing. Yet, there was considerable debate among the coauthors about some of the details in the last assessment (SEDAR 2005), as well as in the most recent (August 2009) assessment update. As previously stated, this is not easy work.

Furthermore, this analysis is specific to red snapper, not a blanket recrimination of artificial reefs and artificial reef programs. There are clear examples in the literature where artificial reefs benefit fishes and ecosystems in which they have been employed, especially in cases where artificial reefs are used to mitigate for loss or injury to natural reefs, or to reduce destructive diving and fishing pressure on natural reefs (Bortone 1998; Pitcher and Seaman 2000; Claudet and Pelletier 2004; Page et al. 2007, among others).

\section{The science}

The debate about whether artificial habitats attract red snapper from nearby natural habitats or actually enhance production of new biomass (i.e., the attraction vs. production debate) has been called meaningless and un-resolvable (Shipp 1999; Shipp and Bortone 2009). This subject often is debated in broad form for all reef-associated species and, as such, may be un-resolvable in the broader context. However, it is more tractable for a single species or life stage, although still difficult due to the scale and complexity of needed studies. We believe that red snapper is one species for which sufficient study has occurred. The calculations of cohort-specific production are straightforward and well known (Box 1-See Electronic Supplementary material, Ricker 1975), although estimates of some of the vital rates necessary for the calculations admittedly are difficult to obtain. For red snapper, growth rates of individual fish are obtained routinely by using increments deposited annually in otoliths that provide accurate age estimates (see review by Fischer 2007), making it possible to determine schedules of weight-at-age, and catch-at-age for individuals, and the cohort, respectively, the latter when rates are averaged over many individuals sampled over a significant portion of the stock (Box 1-See Electronic Supplementary material, Ricker 1975). 
Red snapper cohort (year class) biomass and its relationship to growth and mortality rates, biomass production and year class success

In the following section, we review some basic concepts explaining how growth and mortality relate to biomass production and year class success, and how productivity is a product of these vital rates.

\section{Growth}

Growth of red snapper in the Gulf of Mexico has been well studied (see Fischer 2007 for review). Data in Fig. 1 are based upon a large, Gulf-wide study funded by NOAA's Marine Fisheries Initiative program to evaluate spatial variability in red snapper population demographics by collecting and aging more than 1,000 fish from each of three areas (i.e., Alabama, Louisiana and Texas). Although the oldest fish aged in this study was 45 years (Fischer et al. 2004), other reports have documented red snapper ages $>50$ years old (Render 1995; Baker et al. 2001; Wilson and Nieland 2001, ages 54, 53, and 55 years respectively). These maximum ages are much older than previously reported, even as recently as the 1980 s (maximum age $=15$ years, Nelson and Manooch 1982), and reflect the rapid growth in our knowledge of red snapper from the 1980s until present.
Growth can be expressed as absolute growth (length- or weight-at-age) as in Fig. 1, or as instantaneous or specific growth, which is a rate. Length-atage in Fig. 1 is depicted in the form of standard vonBertalanffy growth curves fit to data from each state individually (Patterson et al. 2001; Fischer et al. 2004) indicating that Louisiana (LA) and Alabama (AL) fish exhibited similar growth and rates, while those from Texas (TX; in terms of length-at-age) were not growing as fast.

What could motivate these growth differences? Some research suggests that the spatial arrangement of reefs on the shelf may be contributing to lower growth (Lindberg et al. 1990; Strelcheck et al. 2005; Shipley 2008) because of increased competition for food among residents of closely spaced reefs, and behavioral interactions between highly gregarious species (Frazer and Lindberg 1994; Lindberg et al. 2006). The Texas Artificial Reef Program ("rigs to reefs" and "ships to reef", http://www.tpwd.state.tx.us/ landwater/water/habitats/artificial_reef/), unlike LA and AL which deploys reefs that are spaced more widely, creates very large reefs out of multiple decommissioned platforms as well as large sunken liberty ships placed together in a few locations, often on or near natural hard bottoms in depths from 20 to $80 \mathrm{~m}$ (Campbell 2008). While reefs from both artificial materials (ships and platforms) are large in size,
Fig. 1 Length-at-age of red snapper collected from three locations in the Gulf of Mexico (from Fischer et al. 2004). These relationships are derived from the same samples used in Fig. 2

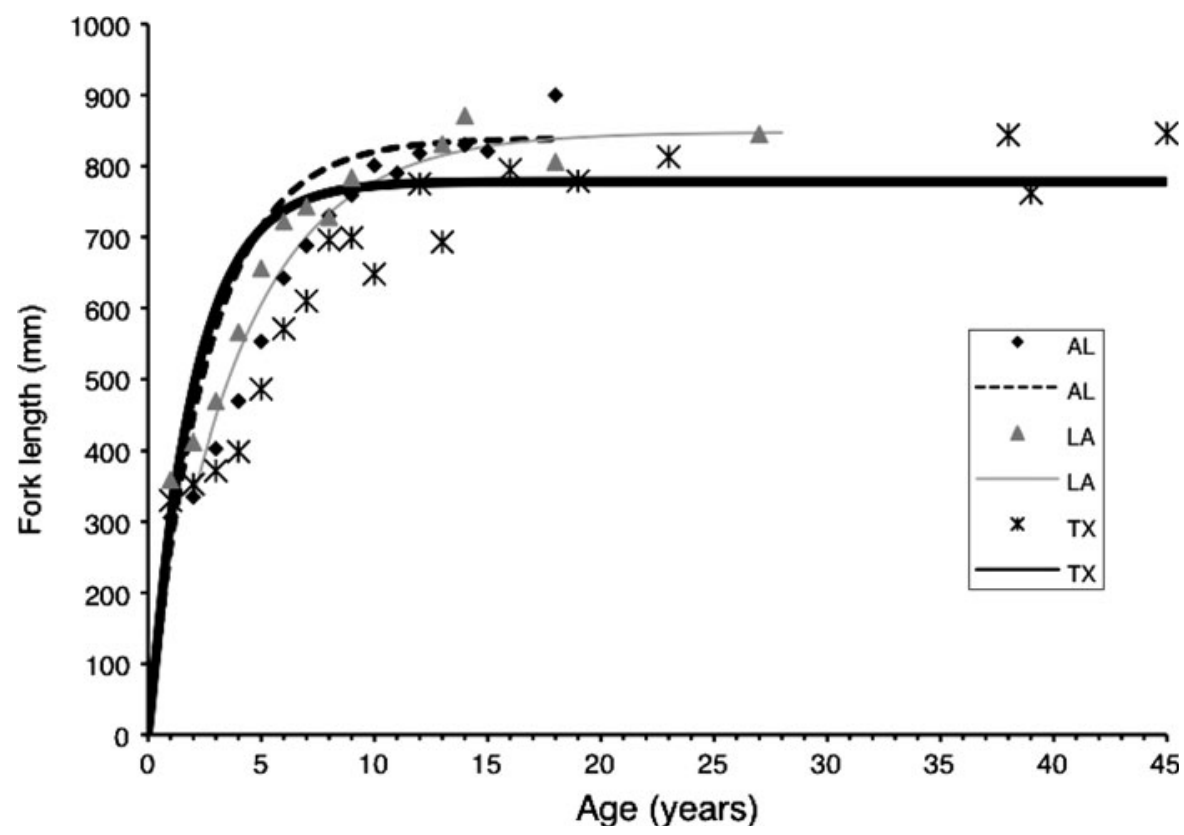


decommissioned platforms are usually more complex than the gutted hulls of ships, further complicating direct comparisons of fish population responses between reef type and spatial location. Unfortunately, it is impossible to provide a more detailed comparison of the effects on red snapper of artificial reefs across a range of reef size and complexity because there is no record of the types and configurations of reefs deployed off Alabama, as the state does not require reefs builders to report such specifics despite the fact that more than $4,500 \mathrm{~km}^{2}$ of the Alabama shelf has been set aside for artificial reef deployment. That said, the role of Gulf oil and gas platforms as fish habitat, including red snapper, has recently been reviewed (VERSAR 2009), and these large structures appear to function quite differently from small, relatively low relief artificial reefs typical of those deployed off Alabama and the Florida panhandle. Red snapper harvested on the west Florida shelf are mostly associated with natural habitats.

We calculated the mean weight of red snapper from ages 30 to 50 years old $(\bar{X}=10,147 \mathrm{~g})$; mean age of these fish is 37 years (from the data used in Fig. 1). Assuming that red snapper recruit to artificial and natural reefs at or near age 2 (Patterson et al. 2001), the estimated instantaneous growth rate from ages 2 to 37 years is $G=0.06$ year $^{-1}$ (Box $1-$ See Electronic Supplementary material) based upon a mean weight at age 2 of $1,049 \mathrm{~g}$ (mean weight of 964 age-2 red snapper collected from LA, AL, and TX in almost equal numbers). However, because growth rate is age-dependent, we also estimated growth rates from ages 2 to 6,6 to 10 , and 10 to 37 . These rates are $G=0.42$ year $^{-1}, \quad 0.09$ year $^{-1}$ and $<0.01$ year $^{-1}$, respectively, ignoring the geographic variability shown in Fig. 1. It is also important to recognize that in general, growth rate scales to mortality rate in nature (i.e., younger fishes may be growing faster but they also die faster; Houde 1996).

\section{Mortality}

The instantaneous rate of total mortality $(Z)$ is commonly estimated from catch curves (plots of frequency-at-age) of adults after entry into the fishery, i.e., as the slope of the regression of the descending limb of the plot of the $\log _{\mathrm{e}}$ frequency on age (Ricker 1975). Figure 2 shows this decline well for red snapper, with many fish being captured prior to reaching size of full vulnerability to fishing (age 1.52 years), after which catch-at-age declines steeply. Data used in Fig. 2 were obtained by collecting samples $(>1,000$ fish in each area) at commercial and recreational ports of call Gulf-wide (i.e., AL-west Florida (FL), LA and TX), and results are similar to those from other studies in the US Gulf (Fischer 2007).

Instantaneous total mortality rate $(Z)$ is then often partitioned into natural $(M)$ and fishing mortality $(F)$ components such that $Z$ is assumed to be the sum of the component parts of $F$ and $M$. In the absence of bycatch mortality, $Z=M$ (Box 2-See Electronic Supplementary material) until fish grow large enough to become vulnerable to fishing. For fish populations, it has been demonstrated that $M$ generally is sizeand/or age-specific; younger, smaller fishes have higher rates that decline and stabilize sometime during the first year of life (Houde 1996; Lorenzen 1996).

From a life history perspective, fish like red snapper are bet-hedgers in that a single female will
Fig. 2 Age-frequency distribution of red snapper catches from three locations in the Gulf of Mexico (from Fischer et al. 2004)

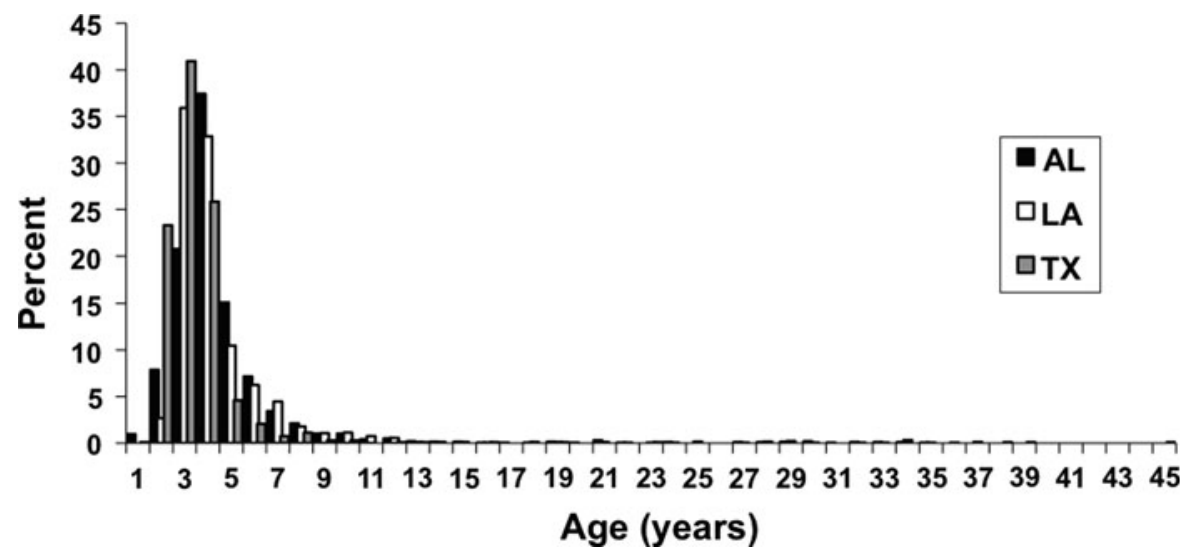


produce millions of very small eggs over her considerable lifetime (Jackson et al. 2007), with each egg having a very small chance of survival to adulthood $(<0.1 \%$; Fuiman 2002); in most years any given female may not produce a single survivor. Bet-hedgers solve this problem by investing minimal energy into developing each egg; large batches of eggs are freely broadcast into the water column with no parental care. Longevity coupled with high fecundity, and protracted spawning seasons provide many chances for a population to produce an occasional strong year class (Winemiller and Rose 1992, 1993; Houde 2008). Red snapper in nature may only need to produce a strong year class every 5-10 years to keep the population stable, able to sustain a reasonable harvest, and evidence suggests that even in good years relatively few females contribute to a given year class (Gold and Saillant 2007). Apparently red snapper have the reproductive capacity and potential to significantly capitalize when opportunities for favorable reproductive success exist. For example, estimates of relative year class strength over a 20 -year period show several dominant year classes $(1989,1995,2004,2006)$, while during this same period the magnitude of the indices varies by a factor of four with no evident trend in recruitment (Allman and Fitzhugh 2007; SEDAR 2009). The absence of trend over this 20 -year period does not support the view that long-term improvement (or deterioration) in habitat or environmental conditions are operating stock-wide.

Rates of $M$ are difficult to estimate, especially during early life, because mortality is rarely observed and estimation typically requires successive samples from a single cohort (year class) over time. For species with life history strategies similar to that of red snapper, $M$ rates are highest while eggs and larvae are planktonic (Houde and Zastrow 1993), i.e., about $20 \%$ per day for larvae of marine shelf species, with rates even higher still for eggs. High mortality rates of eggs and larvae lead to rapid declines in cohort biomass of most marine fishes over the first few days or weeks (Houde 1989a, b; Winemiller and Rose 1992, 1993). This period of rapid decline in biomass is evidenced as the period in life where cohortspecific $G$ is less than cohort-specific $M$ and is a critical time for determining the number of fish that transition to early juveniles. Once small juveniles settle to the bottom, there appears to be a spike in rates immediately after settlement for many species (see Able et al. 2006 for review), followed by rapid decline in rates thereafter. While no estimates of mortality rates for planktonic red snapper exist, recent work on young juveniles show that $M \mathrm{~s}$ of age-0 snapper are high $\left(M=0.98-3.7\right.$ year $\left.^{-1}\right)$ during and following settlement on sand and mud substrates, and may increase when the density of red snapper recruits increases (Rooker et al. 2004; Szedlmayer 2007; Brooks and Powers 2007; Wells et al. 2008b; Gazey et al. 2008; Gallaway et al. 2009; SEDAR 2009; $M=2.0$ year $^{-1}$ was used for model projections in the 2009 red snapper assessment update). At some point cohort biomass ceases to decline, when increasing biomass via growth is equivalent to biomass lost via mortality $(G=M)$. It is before and during this time that course control of year class success is likely exercised because only small differences in $M$ during the period when mortality rates are at their highest can cause order of magnitude variation in the number of survivors to later life stages (Houde 1987, 1989a, b, 2008). Once past the life stage where $G=M$, a cohort or year class will increase in biomass $(G>M)$ to a point later in life where $G=M$ again, followed by another period where $G<M$ when cohort biomass again declines as old members of the cohort grow slowly and die. Red snapper most certainly follow this same pattern and year class success is likely determined for red snapper by subtle changes in $M$ during the first year of life before they recruit to artificial reefs (Strelcheck et al. 2005; Wells et al. 2008b; Gazey et al. 2008), which is entirely consistent with what is known about other fishes with similar life-history strategies (Houde 1987, 1989a, b, 1996, 2008).

Natural mortality rates of sub-adult and adult red snapper after they have recruited to structured habitat also are difficult to estimate, because sampling of a cohort (year class) through time in the absence of fishing is now impossible. Many other stocks suffer from this same problem; thus numerous methods have been developed to estimate $M$ objectively for adult fishes from exploited populations, many of which are based upon longevity (Box 2-See Electronic Supplementary material). Solving these equations for $M$ in Box 2-See Electronic Supplementary material for $T_{\max }=54$ year provides estimates of 0.08 year $^{-1}-0.11$ year $^{-1}$, respectively.

Whether or not $M$ is 0.08 year $^{-1}$ or 0.11 year $^{-1}$ based upon the methods in Box 2-See Electronic 
Supplementary material, or 0.10 year $^{-1}$ as used in the most recent agency benchmark assessment (SEDAR 2005), it illustrates the point that biomass of a red snapper cohort (year class) after age 1 is likely to increase only during a few years when $G>M$; afterward growth rate slows and biomass begins to decline $(G<M)$ because mean $G$ year $^{-1}$ for red snapper between ages 10 and 37 is low $\left(<0.01\right.$ year $\left.^{-1}\right)$. For many species, the point at which cohort-specific biomass begins to decline later in life is related to a shift in the amount of energy (a function of food consumed) that sexually mature adults devote to somatic (body) growth compared gonadic growth (production of spawning products) i.e., eggs in the case of females. Thus, it is likely that $G$ becomes less than $M$ for red snapper before or around the age that full reproductive potential is reached (age 14-15 years; Fig. 3), which stresses both the importance and challenges of rebuilding age structure in the Gulf red snapper population.

Reproductive potential lost as biomass as the cohort grows older is offset for many years by increased egg production in older spawners because these larger females produce more eggs (Campbell 2008; Walters et al. 2008a; Venturelli et al. 2009). This also implies that fishing pressure on red snapper by the directed fishery is highest during the time when biomass production is highest and continues,

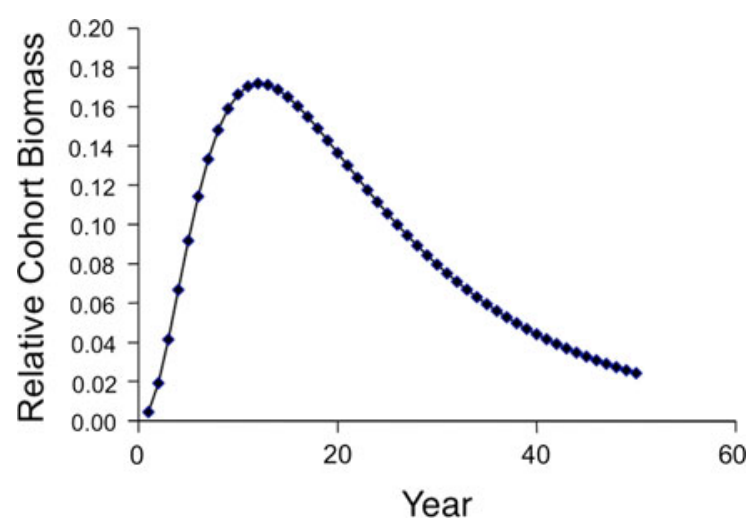

Fig. 3 Red snapper relative cohort biomass estimated from survivorship (survivors per recruit; $F=0$ ) to age and mean body weight at age, which was estimated from vonBertalanffy growth parameters $(K=0.18)$ reported in SEDAR (2005). Annual survival rate was estimated by assuming that natural mortality rate $M$ is inversely proportional to body length (Lorenzen survival model, Lorenzen 2000), dropping to an asymptotic adult $M$ of 0.08 but to a lesser degree on older age classes that are responsible for most of the egg production.

\section{Does available habitat for age $1+$ and older red snapper limit population size?}

Given the information on $G$ and $M$ above, the premise that year class success in red snapper is not determined until fish are between 1.5 and 2 years old, or at the time when they largely begin to inhabit reefs as sub-adults, is inconsistent with a periodic, or bet-hedging, life history strategy (Winemiller and Rose 1992, 1993). For example, there is a longstanding debate among reef researchers about what limits population size: (1) the supply of new recruits from the plankton; or (2) the availability of habitat for newly settled recruits. As we have demonstrated above, fish, including reef fish, are most abundant when they are young. Some believe that the availability of interstices (i.e., small hiding spots) for newly settled post-larvae and juveniles can be limiting; those individuals not finding refuge suffer higher predation rates. In this case, mortality is thought to be density-dependent (Forrester 1990; Holbrook et al. 2000; Forrester and Steele 2000, 2004). It should be noted, however, that age- 0 red snapper rarely recruit directly to high-relief natural or artificial reefs, rather they settle on sand/mud substrates and transition to more structured habitat with size and age (Patterson 1999; Patterson et al. 2005; Wells et al. 2008a, b; Gallaway et al. 2009). It is this transition that makes them vulnerable to shrimp trawling.

Others believe that the supply of reef fish larvae is limiting, with good year classes being determined by density-independent factors that occur while larvae are in plankton prior to settlement on the reef (Doherty and Williams 1988; Doherty and Fowler 1994a, b; Milicich and Doherty 1994; Booth et al. 2000; Sale 1991, 2002). In neither of the above scenarios is habitat for adults limiting; many studies have shown that adult fishes usually do not saturate reefs, especially in exploited populations (Doherty and Williams 1988; Doherty and Fowler 1994a, b; Booth et al. 2000). In nature, however, it is unlikely to be a simple dichotomy, as more than one factor can be limiting at different life stages (multiple causalities). Other post-settlement factors can significantly 
modify recruitment patterns and year class success, and it is conceivable that availability of adult habitat can been limiting for species that require specific substrates to complete their life cycle (Winemiller and Rose 1992).

The availability of low-relief, natural habitat for post-settlement red snapper (ages 0 and 1) has been suggested to be limiting (Gallaway et al. 2009) because the numbers of age 0 and 1 red snapper have been poorly correlated, suggesting that densitydependent mortality is occurring sometime early in the second year of life. However, age-1 red snapper are considerably more vulnerable to shrimp trawls than age-0s because of mesh sizes used by shrimp trawlers (Gallaway and Cole 1999), making it difficult to draw strong inference about the role of low-relief natural habitat and its availability (see below) in the shallow Gulf as it relates to the numbers of juveniles that ultimately recruit to higher relief natural and artificial reefs.

We argue that the amount of habitat for an adult bet-hedger like red snapper, especially artificial habitats that account for $<5 \%$ (Stanley and Wilson 2003) of total useable habitat as compared to suitable natural habitats, probably does not limit recruitment or population size. The useable habitat increase due to artificial habitats is likely less even than the $5 \%$ reported above because this estimate includes all oil and gas platforms, many of which are not suitable habitat for red snapper, especially the inshore to midshelf platforms in the northwestern Gulf that are subjected to Mississippi River discharge.

Oil and gas platforms, that began appearing in the western Gulf in the late 1940s, function secondarily as large artificial reefs (Shipp and Bortone 2009). However, platforms bear little resemblance to either natural reefs or most artificial reef materials intentionally placed to promote fisheries, and it is possible that artificial reefs primarily attract fish to shelter rather than directly producing more fish. From a life history perspective, even if artificial reefs have increased carrying capacity, but not the intrinsic rate of population growth, and the stock is still at low abundance, adding habitat would not have had any significant positive impact on stock biomass. Nor would it increase the over fishing level (OFL) as a proportion of biomass, rather it would only increase the potential yield. This is true unless artificial reefs provide habitat of substantially higher quality than existing natural reefs. Furthermore, the attraction of a diverse suite of predators (e.g., jacks, mackerels, groupers, sharks, cobia, bluefish, other snappers, etc.; VERSAR 2009) by deploying artificial reefs into shallower red snapper nursery habitats, where population size is much more likely to be regulated (Wells et al. 2008b; Gazey et al. 2008), could actually have a negative impact on stock productivity by increasing predation (Hixon and Beets 1993; Hixon and Webster 2002; Walters et al. 2008b). Therefore, we infer that red snapper life history is inconsistent with the notion that habitat limitation (Gallaway et al. 2009; Shipp and Bortone 2009) is a strong actor in regulating population size in this species.

\section{Fishing and its effect on production}

The process to assess the status of the red snapper stock is complex and is discussed only briefly here. To begin, a wide array of biological data is collected and summarized. Detailed information on all biological data is available in the 2005 red snapper assessment (SEDAR 2005) and the 2009 assessment update (SEDAR 2009). Biological data included are primarily on age structure of the landed catch, age at first spawning, fecundity, ratio of males to females, $M, Z$, $G$, and spawning behavior. Fishery dependent data required includes types of fishers (commercial versus recreational), fishing gear (longlines, rod and reel, trawls, etc.), landings by each gear and fisher, the fishing effort by fisher type, and information on size and age of fish harvested by each gear. Fishery specific information is also considered such as the effect of regulatory actions on landings (which change through time and alter fishery observed size/age structure of catch), vulnerability schedules to different gear types by fish size, discard rates (release rate of undersized fish), and discard mortality rates (proportion of these released fish that die), and the time and geographic location of the catches. Also in the assessment, geographical boundaries of different stocks or populations are defined. From the combined biological and fisheries data, the current status and condition of the stock is defined and predictions are made about how it will respond to varying levels of $F$.

Recall the importance of the ratio $G: M$ in the production equations found in Box 1-See Electronic Supplementary material (i.e., when $G>M$ cohort 
biomass increases, when $G<M$ cohort biomass declines, and the age-frequency data shown in Fig. 2). Additionally, recall that $Z$ is the sum of its component parts $F$ and $M$. If we estimate the rate of decline from the age data in Fig. 2, the slope of the descending arm is about $47 \%$ per year (apparent total instantaneous mortality $\bar{Z}=0.63$ year $^{-1}$ for LA, AL and TX combined) which is consistent with Gitschlag et al. (2005) estimate $\left(0.54\right.$ year $\left.^{-1}\right)$ for red snapper sampled from explosively-removed petroleum platforms in the north western Gulf, as well as an estimate derived from data reported by Szedlmayer (2007) from fish sampled off Alabama using Gitschlag et al. (2005) catch curve methodology $\left(0.82\right.$ year $\left.^{-1}\right)$. Assuming that $M$ for red snapper aged 2 years and older is 0.10 year $^{-1}$, the difference is attributable both to fishing and, since 1990 , to a decline in vulnerability of older red snapper to fishing.

As such, biomass production of an exploited population is based upon $Z$, which is the sum of $F+M$. In the most recent red snapper benchmark assessment (SEDAR 2005), estimated $F$ at ages 2-6 and 2-10 averaged 0.74 and 0.59 year $^{-1}$, respectively. If our goal is to keep the ratio $G: Z$ near 1 , i.e., to keep biomass constant through time, these $F$ s are too high and the ratio now is $<1.00$ even for ages $2-6$ when fish are growing rapidly (given a $G$ of 0.42 year $^{-1}$ ). Consequently, it is possible for biomass to decline even when red snapper $G$ s are high because the $Z$ exceeds this estimated growth rate. As in most assessments, estimates of $F$ in the most recent red snapper assessment are somewhat uncertain; however, these errors would have to have been very large, and $F$ estimates biased very high, for the stock actually to have been experiencing positive population growth prior to the recent regulatory reductions in fishing mortality.

The relationship between $G$ and $M$, and their importance to production explains why fishing has been shown to be a significant source of uncertainty about whether artificial reefs are capable of producing new fish biomass (Powers et al. 2003). This uncertainty is attributable to the role that fishing plays in density-dependent population regulation (Shepherd and Cushing 1980; Myers 1995; Lorenzen and Enberg 2002), and whether $F+M$ is sufficiently high to override natural population regulators such as habitat limitation. To add perspective, a recent ICES Working Group on Ecosystem Effects of Fishing
Activities (ICES 2009) made recommendations concerning the likely rates of sustainable removal rate of fishes with life histories similar to that of red snapper, but for which formal stock assessments are unavailable. They recommended following an approach using the natural mortality rate for species to place a maximum bound on an allowable $F$, i.e., the $F=M$ strategy (see Clark 1991; García et al. 2008), and using maximum age $\left(T_{\max }\right)$ to estimate $M$ if possible. Two different lines of support were provided for an $F=M$ strategy for relatively long-lived and latematuring species. The first rationale is that doubling mortality on long-lived species (if $F=M$ then $Z=2 \times M$ ) might be near the limit of their ability to compensate for increased mortality through density-dependent increases in productivity (Myers and Mertz 1998; Walters and Martell 2004; García et al. 2008). The second is that many long-lived species that have been targeted in fisheries have undergone major declines in abundance when $F$ exceeded $M$ (Musick 1999; Heifetz et al. 2007; Love et al. 2005).

There is additional empirical evidence in support of our conclusion that red snapper remain overfished. Fischer (2007) provides a review of vonBertalanffy growth parameters $(K)$ from studies of red snapper in the Gulf. Growth parameter estimates $(K \mathrm{~s})$ from Fischer et al. (2004) are inversely correlated to estimates of effective population size (i.e., the number of females contributing to any given year class) by region provided by Gold and Saillant (2007). The highest $K \mathrm{~s}$ were derived from the regions with the lowest effective population size (AL and TX). Moreover, red snapper off Alabama are juvenescent and maturing at earlier ages than normal (Jackson et al. 2007), and red snapper collected more recently by Nieland et al. (2007) off Louisiana appear to be reaching smaller size-at-age. Juvenescence in fish population occurs when $Z$ on adults is high, and fishers selectively remove larger, faster growing, late maturing individuals more rapidly because these fish are the first to become vulnerable to fishing (Trippel 1995; Trippel et al. 1997; Murawski et al. 2001). As such, per capita food resources increase for individuals that remain; some of these individuals respond by maturing at earlier ages. Those that that are genetically predisposed to mature earlier then have a selective advantage under fishing pressure and a greater chance of contributing spawning products over late-maturing individuals. This ultimately leads to directional 
selection for early maturing females in the population (Rijnsdorp 1993; Kraak 2007; Law 2007 and papers in theme session entitled Disentangling the causes of maturation trends in exploited fish populations, Mar Ecol Prog Ser. 335 (2007)). Both of these phenomena are well-documented symptoms of overexploitation that would not be evident at recent annual harvest levels (9.12 million $\mathrm{lbs}$ ) if stock size and carrying capacity in the Gulf had dramatically increased.

\section{The faith}

The role of artificial reefs in the management (policy), population dynamics and status of red snapper in the Gulf has been controversial. The scientific community and fishers have debated this issue many times over. We recognize that oil and gas platforms and artificial reefs (collectively ARs) are associated with successful recreational and commercial fisheries, and some have argued that the Gulf red snapper stock has been enhanced by the addition of structure as habitat for adults (Shipp and Bortone 2009). So we return full circle to the attraction versus production (AvP) debate. When examined relative to earlier AvP conceptual models (Bohnsack 1989; Lindberg et al. 1990; Grossman et al. 1997; Powers et al. 2003), and as we describe it in this paper, a case for AR enhancement of red snapper production is highly doubtful. As we have pointed out, it is possible that ARs have increased the vulnerability of red snapper to fishing by aggregating fish closer to shore, and perhaps have increased predation mortality by attracting piscivores into nursery areas for juveniles (Cowan et al. 1999). We also know that fishing mortality for red snapper is quite high (SEDAR 2005, 2009) and that much of this fishing (from the recreational sector) occurs over ARs. It has been shown that red snapper gain little nutrition from ARs, moving large distances away from structured habitat each day to forage on the benthos (see review by McCawley and Cowan 2007; McDonough 2008). This also is true of juvenile and adult red snapper found on natural reefs (Wells et al. 2008a). Site fidelity to ARs by red snapper is moderate to low (see Patterson 2007 for review; Diamond et al. 2007; Westmeyer et al. 2007; McDonough 2008), and residence around standing platforms with high vertical relief may cause a significant increase in vulnerability to predation because of the large numbers of piscivores frequenting these anomalous structures when compared to natural habitats in the Gulf (VERSAR 2009). This situation is exacerbated by barotrauma that makes red snapper regulatory discards less able to avoid predators after fish are released (Campbell 2008). Even when comparing the findings from works referenced above with other results of studies of red snapper diet (Szedlmayer and Lee 2004; Ouzts and Szedlmayer 2003) and site fidelity (Szedlmayer and Shipp 1994; Schroepfer and Szedlmayer 2006), the differences in reported results appear to be more dependent upon dispute about prey habitat affinities, and how site fidelity is defined than significant differences in results among studies.

The argument that ARs have increased red snapper stock size appears to be based upon two key observations. First is the observation that landings of red snapper increased in the eastern Gulf concurrently with large numbers of ARs deployed in this area beginning in 1986. Second, there has been a shift in overall landings from the eastern to western Gulf in concert with the arrival of large numbers oil and gas platforms off Louisiana beginning in 1947 (Shipp and Bortone 2009). These changes are well supported by data (Porch et al. 2007) and we do not deny they occurred. Where we disagree is in their interpretation. For example, there is a positive correlation between red snapper landings in the eastern Gulf and the establishment of the 4,500 $\mathrm{km}^{2}$ Artificial Reef Permit Zone off AL, which began in 1986 with the creation of the Hugh Swingle Permit Area. This occurred just prior to the realization that red snapper management in the Gulf was necessary to reduce the risk of further stock collapse. Since 1986, many ARs have been deployed in this area $(10 \mathrm{~s}$ of $1,000 \mathrm{~s}$; Patterson 1999; Bailey et al. 2001) and red snapper catches from the permit area have gone up as the number of reefs (and fishing effort) increased. This relationship has been cited as evidence of the beneficial effects of ARs on the red snapper population in the Gulf (Shipp 1999).

However, we contend that this is a spurious relationship created by knowledge and law, i.e., the curious juxtaposition of new scientific knowledge about red snapper and fortuitous changes in statutes governing fisheries management. When red snapper management began in the late 1980s, the fishery had existed for about 100 years (Moe 1963; Camber 1955 reviewed in Porch et al. 2007), red snapper catches 
had declined Gulf-wide, and the commercial fishery had been largely extirpated from the eastern Gulf. Early management regulations targeted both the commercial and recreational sectors of the fishery by establishing a TAC of 3 million lbs annually for the commercial fishery, and implementation of restrictive bag limits for the recreational fishery (Hood et al. 2007). Additionally, management agencies identified the potential issue of juvenile red snapper bycatch in the shrimp fishery and the role of reducing bycatch to aid in stock recovery (Goodyear 1995). At that time, bycatch reductions of $40-50 \%$ were believed to be necessary to recover red snapper, in addition to reductions in harvest of adults (Goodyear 1995). This two-pronged management (and policy) approach of curtailing harvest of adults and reducing juvenile bycatch to increase recruitment has been the primary recovery formula for red snapper ever since (Hood et al. 2007).

This management approach also stimulated substantial research into all aspects of red snapper population ecology. Outcomes from this research have greatly expanded our knowledge of red snapper and motivated revisions to key life-history parameters used in stock assessments. For example, new and improved methods of aging and age verification of red snapper using increments in otoliths have become much more widely applied as has collection efforts for representative age samples. What followed from these efforts was a progression of red snapper age estimates that extended estimated longevity from 15 years in the early 1980s (Nelson and Manooch 1982) to 55 years, as we know today (Fischer 2007 for review). As shown earlier, estimates of maximum age are commonly used in simple equations to estimate $M$ and to serve as a reference point from which to compare exploitation levels $F$. Thus changes in maximum age can lead to large changes in $M$ and in turn assessments of the relative magnitude of $F$.

In 1996, the Magnuson-Stevens Act of 1976 (MSA; U.S. Public Law 94-265) was reauthorized and revised as the Sustainable Fisheries Act (SFA; U.S. U.S. Public Law 104-297), which contained stricter conservation standards than the MSA (e.g., definitions of overfished and overfishing based upon discrete biological benchmarks). These standards required development of rebuilding plans to recover overfished populations within strict time constraints. For fish species that could not be recovered within
10 years following a moratorium on harvest, the law required recovery in 1.5 generations in the life of the fish under management. The scientific knowledge about increased longevity and the law requiring rebuilding schedules to be linked to generation time made it possible for TACs of red snapper to be increased over time, finally to 9.12 million $\mathrm{lbs}$, because of new longevity information that lengthened the time permitted for rebuilding the stock until 2032. However, all of the TAC increases that occurred between 1990 and 1996, and continued high TACs after 1996, also were predicated upon $>50 \%$ reductions in shrimp trawl bycatch of juveniles that, if achieved, permitted a risk-prone (constant catch) harvest strategy that preserved high catches for the directed fisheries (Hood et al. 2007). This strategy also required catch levels to remain constant for the entire rebuilding period to recover the stock in 2032, in the face of complaints by fishers who were (and are again) seeing more fish as the stock recovers, especially when strong year classes enter the fishery. There were many attempts by science advisors to assuage fisheries policy makers in the Gulf to adopt a less risk-prone approach, without success, even as it became apparent that a technological solution to reducing numbers of red snapper from the shrimp fishery bycatch was unlikely (Watson et al. 1997; NOAA 2004). Clearly, the above history does not capture all details. For more detailed information, see Hood et al. (2007) and the Advisory Panel Reports found at the following weblink (Reef Fish Stock Assessment Panel Reports from 1990 forward at http://www.gulfcouncil.org/, then Library, then Downloadable Files).

\section{A historical perspective}

Based upon a historical reconstruction of the red snapper fishery from its inception off Mobile, AL and Pensacola, FL in the late 1880s until today, Shipp and Bortone (2009) argue that ARs have substantially increased red snapper stock size in the US Gulf. These authors infer that red snapper stocks were smaller in the eastern Gulf and effectively absent from the western Gulf until ARs were deployed. In the eastern Gulf, inference is drawn from the recent $20+$ years of higher catches off Alabama, compared to lower catches and short-lived fisheries for red snapper in 
the late 1870 s to early 1900 s. While we do not dispute the historical record, there is an alternate interpretation of the old landings data, and where on the shelf the fishery was prosecuted. In that region of the eastern Gulf, there is considerable low-relief, hard-bottom, shell-rubble habitat that was formed during the last sea-level transgression (Schroeder et al. 1988; Kennicutt et al. 1995; Patterson et al. 2005; Dufrene 2005). Much of this habitat has been repeatedly trawled and broken up over time, but recent work in areas less impacted by trawling indicates that these inshore habitats still support juvenile red snapper and likely once supported adults as well (Wells et al. 2008a, b). In work off Alabama and Mississippi, Wells and colleagues compared these habitats inside and outside of the Alabama Artificial Reef Permit Zone, including some stations in the Hugh Swingle Permit Area, which has been a de facto no-trawl zone since 1986. Habitat that had not experienced recent trawling was more complex and supported a more diverse community of benthic invertebrates and demersal fishes, including juvenile and adult red snapper up to ages $5+$. In addition, the diet consumed by red snapper on these habitats was more diverse than on similar habitats outside of the no-trawl zone. We suggest that prior to extensive trawling, these habitats likely had diverse fish communities, and thus may have been the source of red snapper in the early days of the fishery off Mobile. Of course, it is impossible to know how dense, or how abundant, red snapper were on these inshore habitats, but they are less dense on low relief habitats today than on nearby ARs, even in the no-trawl zone. Is it possible that the red snapper fishery was founded on these inshore habitats, that then were relatively quickly depleted of fish, forcing fishers to prospect for new fishing grounds without ever discovering the higherrelief, shelf-edge features such as the Alabama Alps and Pinnacles (Schroeder et al. 1988; Kennicutt et al. 1995) where red snapper likely were more abundant (Gledhill 2001)?

The findings of Moe (1963) support this alternate interpretation. A survey of offshore fishing in FL completed in the early 1960s provides information about habitat types and fisheries on the Northwest Florida Coast (from east of Panama City, FL to the AL state line). The report states that the bottom is composed of sand and limestone, with rock outcroppings that are more numerous in the eastern section of the area than in the west. The report further indicates that rock outcroppings generally occur in waters greater than 12 fathoms, and are found in the bottom of gullies and holes formed in the irregular sandy bottom, or along the sides of ledges and cliffs that drop to deeper water. The cliffs and ledges generally lie parallel to the depth contours. The relief of these features varies from a few feet to 11 or 12 fathoms. Further, Moe reported that "the most sought after and numerous fish in the catch of the sport and commercial vessels is the Red Snapper. The fishing vessels seek out rocky areas, wrecks of ships and airplanes, and other irregularities of the bottom as these areas are most productive" (page 50, paragraph 1 and 2).

This scenario also appears be plausible in the western Gulf where prospecting in the early days failed to find productive fishing grounds off the LA and northeastern TX coasts (Shipp and Bortone 2009). But again, it seems likely that the fishers in the early days may have failed to locate the numerous shelf-edge features well offshore of LA and TX, which in recent history have been considered to be one of the centers of abundance of the red snapper stock in the northern Gulf (Goodyear 1995). In fact, Gledhill (2001) found that these shelf-edge banks contained a higher proportion of snappers (red and vermilion Rhomboplites aurorubens) to total biomass than on similar features in the eastern Gulf. This does not discount the correlation between increased catches of red snapper in the western Gulf and the increasing number of oil and gas platforms, which serve as de facto ARs (Shipp and Bortone 2009). However, we see this as a chicken and egg argument. Is it likely that few red snapper existed in the northwestern Gulf before ARs were constructed, or did these man-made structures provide a movement corridor for fish to move inshore where they are more accessible to fishers? This mechanism of cross-shelf movement by reef-associated fishes has been postulated both for natural and artificial habitats in the eastern Gulf (USGS 2008).

Another salient point that was overlooked in the historical reconstruction of the red snapper fishery (Shipp and Bortone 2009) was the enormous change in hydrographic parameters in the northcentral and northwestern Gulf brought about by flood protection measures on the Mississippi River that began following the 1927 flood (Barry 1997). These measures took decades to complete (until the early 1970s when Atchafalaya River discharge was fixed at $30 \%$ of total Mississippi River discharge), but the end result was 
channelization of the river using levees and the upstream construction of dams for power generation, both of which acted to greatly reduce the amount of freshwater and sediments reaching the shallow shelf in the northern Gulf, while at the same time stimulating productivity in the water column (Bianchi et al. 2008). Within the last few years, the first author was involved in a program to collect side-scan sonar images of the Louisiana Artificial Reef Planning Areas (PAs) in which were discovered large areas of relatively high-relief, high-reflectance (solid) habitat, especially in those PAs farthest from the Mississippi and Atchafalaya River mouths. While different in origin (lithified delta muds, tops of salt domes) than low-relief features in the shallow eastern Gulf (old beach ridges), their emergence as habitat as sediment loads decreased may well have been coincident in time with the increase in the number of ARs off LA, and the higher catches of red snapper in the region. It is also possible that this habitat may be contributing to apparent recent increases in red snapper recruitment, if indeed habitat is limiting for juveniles, and the stock is finally beginning to recover.

As a final point in the discussion of history, longliners were not prohibited from fishing in depths of less than 50 fathoms in the northern Gulf until 1990 , or about the same time the red snapper stock was most depressed. Coincidently, this also is the time when the number of oil and gas platforms was most numerous in the Gulf. Because larger, older red snapper have a tendency to move off structured habitats as they grow older, these fish were susceptible to longlining prior to 1990 , likely decreasing numbers of older, larger females in the population. While these older fish today are less vulnerable to fishing because of the longline ban and their numbers are slowly increasing (SEDAR 2009), escapement to older ages may still be too low to fill the "hole" in the age structure. Remember, the fish that would be our most productive spawners today ( $\sim 20$ years old) were born during a period when stock biomass was very low and longlining was occurring.

\section{Final thoughts}

From the beginning of red snapper management in the Gulf (see review of the early days by Goodyear
1995), assessment results indicated that significant reductions in bycatch mortality of juvenile red snapper attributable to the shrimp industry, coupled with decreased harvest of adults by the directed fishery, perhaps, could result in rapid recovery of the stock (see Reef Fish Stock Assessment Panel Reports from 1990 forward at http://www.gulfcouncil.org/, then Library, then Downloadable Files). Despite the enormous body of knowledge that has been amassed about red snapper since that time, the message has remained consistent. Given that offshore shrimp fishing effort now (early 2010) is down by as much as 75-85\% (SEDAR 2009) owing to recent coastal storm damage, economic woes, high fuel prices and cheap imported shrimp, bycatch has been declining for the last several years, especially since 2002, and the directed fishery (which also has been negatively impacted by high fuel prices) has recently been constrained by the 2006 MSRA to lower total allowable catches (TACs). Simply put, the recovery formula long prescribed in the agency assessments has finally been realized, although recent estimates of $\mathrm{M}$ for age- 0 and age- 1 red snapper may diminish the role that bycatch reduction can play in recovery of the stock. Even so, recent sampling off LA and the FL panhandle (Dance 2008; SEDAR 2009) indicates that the increase in numbers still is mostly comprised of 3-7 year old fish, but numbers are indeed increasing. Given that artificial reefs and especially oil and gas platforms have been in place for many years (Shipp and Bortone 2009), it seems counterintuitive to award credit to artificial structures for the beginning stages of stock recovery that are just now becoming apparent. This incongruity is particularly exaggerated when considering that stock rebuilding was basically non-existent for 20 years, and not until long prescribed management measures were finally put in place. This may be especially true in the eastern Gulf off AL where the large AR permit zones have created a de facto refuge from shrimp trawling, thus bycatch of juvenile red snapper, making it difficult to differentiate the reef effect from the reduction in bycatch and decreases in destruction and degradation of natural hard bottom habitat.

The above analyses and summary comments are not meant to be an indictment of ARs and AR programs. Legitimate benefits of ARs can and have been achieved (Bortone 1998; Pitcher and Seaman 
2000; Claudet and Pelletier 2004; Page et al. 2007), especially when ARs serve as no-take reserves (Schroeder and Love 2002). However, most agree that goals and objectives of an AR or an AR program need to be explicitly stated in order to assess "performance". When this is done, analyses of measurable parameters relative to stated objectives show benefits ranging from increased consumptive and non-consumptive use, to improved marine protected area performance (Ramos et al. 2007; Claudet and Pelletier 2004).

Recent studies are instructive in reminding all parties that there are highly complex questions of community-scale ecology underlying the single-species "patterns" that we often use to justify large-scale deployments of ARs. For example, substantially modified trophic interactions (i.e., transformations, see Shipp 1999), can develop requiring extensive study and experimentation to resolve; these transformations cause both direct and indirect effects in ecosystems in which they occur, but may not apply to other locations (Powers et al. 2003; Grabowski and Powers 2004; Shipley 2008). We encourage careful study and experimentation, as was done in the papers cited above, and Page et al. (2007), to address spatially-explicit, objective driven, and quantifiable performance of ARs in the Gulf (Strelcheck et al. 2005; Lindberg et al. 2006) and elsewhere. We also believe that improved fishing opportunities and higher catches should not be the only metric used to assess AR performance.

Finally, regardless of the cause(s) of the putative increase in red snapper stock-specific productivity, higher productivity conveys higher potential biomass levels (i.e., carrying capacity), thus resulting in higher, not lower (Shipp and Bortone 2009) rebuilding targets (i.e., over fishing levels (OFL), biomass at

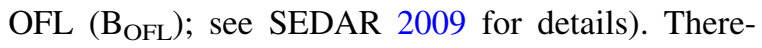
fore, further reductions in annual catch limits (to end overfishing by 2010 and reach OFLs in the long-term) may actually be needed for a more prolonged period of time because we may have higher goals to reach. The assessment models are forward looking because science has recognized that things can and do change in ecosystems. So all of the assessments compare current biological benchmarks to future stock status given a stable age distribution (i.e., a fully complete age structure). Most importantly, if spawning stock biomass is still too low to produce the minimum number of eggs (primarily due to the truncated age distribution, Walters et al. 2008a) to avoid recruitment overfishing, even accepting the likelihood for some recruitment compensation, the debate (including AvP) about artificial reefs is rendered ineffectual. The bottom line is that if carrying capacity for adults has increased, yet escapement to older ages is still too low, we would now have a much larger and longer row to hoe to recover the red snapper stock to $B_{\mathrm{OFL}}$.

In their recent perspective, Shipp and Bortone (2009) argue that the red snapper stock is not only larger, but also is more productive today due to ARs; therefore, red snapper could not possibly be overfished. However, apical $F$ estimates for various fisheries have been quite high (0.4-1.0 year ${ }^{-1}$; Porch 2007), and there are other empirically derived symptoms that the red snapper stock is overfished (Jackson et al. 2007; Nieland et al. 2007). Although estimates are that future yields (i.e., longterm productivity) could be $\sim 2 \times$ higher than any recorded landings (note: landings data are sparse before about 1980), the stock cannot recover to threshold biomass levels at current $F$ rates. Shipp and Bortone (2009) argue further that managers should not have to reach a $\mathrm{B}_{\mathrm{OFL}}$ threshold based upon current (higher) estimates of stock productivity. In effect, they argue that carrying capacity and productivity have increased substantially, while contending that $\mathrm{B}_{\mathrm{OFL}}$ should not scale to these increases. We think this point should be noted by our readers, regardless of the ultimate cause(s) of the presumed higher productivity in the stock. (Note: Porch (2007) lists several as yet untested hypotheses about causes of apparent increases in productivity, with ARs among them). In the meantime, the preponderance of scientific information that is used in the agency assessment process, and the simple arguments made here, do not support the position that artificial reefs have increased red snapper stock size sufficiently to defer compliance with the MSRA.

Acknowledgments We thank two anonymous reviewers for their comments on an earlier draft of this manuscript. None of the authors were compensated for participating in this effort.

Open Access This article is distributed under the terms of the Creative Commons Attribution Noncommercial License which permits any noncommercial use, distribution, and reproduction in any medium, provided the original author(s) and source are credited. 


\section{References}

Able KW, Fahay MP, Witting DA, McBride RS, Hagan SM (2006) Fish settlement in the ocean vs. estuary: comparison of Pelagic larval and settled Juvenile composition and abundance from Southern New Jersey, U.S.A. Estuar Coast Shelf Sci 66:280-290

Allman RJ, Fitzhugh GR (2007) Temporal age progressions and relative year-class strength of Gulf of Mexico red snapper. In: Patterson WF, Cowan JH Jr, Fitzhugh GR, Nieland DL (eds) Red Snapper ecology and fisheries in the US Gulf of Mexico. American fisheries society, symposium 60, Bethesda, Maryland, pp 311-329

Bailey HK, Cowan JH Jr, Shipp R (2001) Experimental evaluation of potential effects of habitat complexity and presence of conspecifics on behavior of young-of-the-year red snapper on artificial reefs. Gulf Mex Sci 19:119-131

Baker MS Jr, Wilson CA, Van Gent DL (2001) Testing assumptions of otolith radiometric aging with two longlived fishes from the Gulf of Mexico. Can J Fish Aquat Sci 58:1244-1252

Barry JM (1997) Rising tide. The Great Mississippi River Flood of 1927 and How It Changed America. Simon and Schuster, New York

Bianchi TS, DiMarco SF, Allison MA, Chapman P, Cowan JH Jr, Hetland RD, Morse JW, Rowe G (2008) Controlling hypoxia on the Louisiana shelf: beyond the nutrient-centric view. EOS 89:236-237

Bohnsack JA (1989) Are high densities of fishes at artificial reefs the result of habitat limitation or behavioral preference? Bull Mar Sci 44:631-645

Booth D, Kingsford M, Doherty P, Beretta G (2000) Recruitment of damselfishes in One Tree Island lagoon: persistent interannual spatial patterns. Mar Ecol Prog Ser 202:219-230

Bortone SA (1998) Resolving the attraction-production dilemma in artificial reef research: some yeas and nays. Fisheries 23:6-10

Brooks EN, Powers JE (2007) Generalized compensation in stock-recruit functions: properties and implications for management. ICES J Mar Sci 64:413-424

Camber CI (1955) A survey of the red snapper fishery of the Gulf of Mexico, with special reference to the Campeche Banks. State of Florida Board of Conservation Technical Series 12. Marine Laboratory, St. Petersburg

Campbell M (2008) Characterization of the stress response of red snapper: connecting individual responses to population dynamics. Dissertation, Texas Tech University

Clark WG (1991) Groundfish exploitation rates based on life history parameters. Can J Fish Aquat Sci 48:734-750

Claudet J, Pelletier D (2004) Marine protected areas and artificial reefs: a review of the interactions between management and scientific studies. Aquat Living Resour 17:129-138

Cowan JH Jr, Ingram W, McCawley J, Sauls B, Strelcheck A, Woods M (1999) The attraction vs. production debate: does it really matter from the management perspective? A response to the commentary by Shipp. Gulf Mex Sci XVII:137-138

Dance MA (2008) Reef fish community structure at unpublished artificial reef sites of northwest Florida: implications for no-harvest refugia. Thesis, University of West Florida

Diamond SL, Campbell MD, Olsen D, Wang Y, Zeplin J, Qualia S (2007) Movers and stayers: individual variability in site fidelity and movements of red snapper off Texas. In: Patterson WF, Cowan JH Jr, Fitzhugh GR, Nieland DL (eds) Red Snapper ecology and fisheries in the US Gulf of Mexico. American fisheries society, symposium 60, Bethesda, Maryland, pp 163-188

Doherty P, Fowler A (1994a) Demographic consequences of variable recruitment to coral reef fish populations: a congeneric comparison of two damselfishes. Bull Mar Sci 54:297-313

Doherty P, Fowler A (1994b) An empirical test of recruitment limitation in a coral reef fish. Science 263:935-939

Doherty PJ, Williams DMB (1988) The replenishment of coral reef fish populations. Oceanogr Mar Biol Annu Rev $26: 487-551$

Dufrene TA (2005) Geological variability and holocene sedimentary record on the northern Gulf of Mexico inner to midcontinental shelf. Thesis, Louisiana State University

Fischer AJ (2007) An overview of age and growth of red snapper in the Gulf of Mexico. In: Patterson WF, Cowan JH Jr, Fitzhugh GR, Nieland DL (eds) Red Snapper ecology and fisheries in the US Gulf of Mexico. American fisheries society, symposium 60, Bethesda, Maryland, pp 189-200

Fischer AJ, Baker MS Jr, Wilson CA (2004) Red snapper (Lutjanus campechanus) demographic structure in the northern Gulf of Mexico based on spatial patterns in growth rates and morphometrics. Fish Bull US 102:593-603

Forrester GE (1990) Factors influencing the juvenile demography of a coral reef fish. Ecology 71:1666-1681

Forrester GE, Steele MA (2000) Variation in the presence and cause of density-dependent mortality in three species of reef fishes. Ecology 81:2416-2427

Forrester GE, Steele MA (2004) Predators, prey refuges, and the spatial scaling of density-dependent prey mortality. Ecology 85:1332-1342

Frazer TK, Lindberg WJ (1994) Refuge spacing similarly affects reef-associated species from three phyla. Bull Mar Sci 55:388-400

Fuiman L (2002) Special consideration of Fish Eggs and Larvae. In: Fuiman L, Werner R (eds) Fishery science: the unique contributions of early life stages. Blackwell Science, New York, pp 1-32

Gallaway BJ, Cole JG (1999) Reduction of juvenile red snapper bycatch in the U.S. Gulf of Mexico shrimp trawl fishery. N Am J Fish Manage 19:342-355

Gallaway BJ, Szedlmayer ST, Gazey WJ (2009) A life history review for red snapper in the Gulf of Mexico with an evaluation of the importance of offshore petroleum platforms and other artificial reefs. Rev Fish Sci 17:48-67

García VB, Lucifora LO, Myers RA (2008) The importance of habitat and life history to extinction risk in sharks, skates, rays and chimaeras. Proc R Soc London B 275:83-89

Gazey WJ, Gallaway BJ, Cole JG, Fournier DA (2008) Age composition, growth, and density-dependent mortality in Juvenile Red Snapper Estimated from Observer Data from the Gulf of Mexico Penaeid Shrimp Fishery. N Am J Fish Manage 28:1828-1842 
Gitschlag GR, Schirripa MJ, Powers JE (2005) Impacts of red snapper mortality associated with the explosive removal of oil and gas structures on stock assessments of red snapper in the Gulf of Mexico. In: Stanley DR, Scarborough-Bull A (eds) Fisheries, reefs, and offshore development. American fisheries society, symposium 36, Bethesda, Maryland, pp 83-94

Gledhill CT (2001) Reef fish assemblages on Gulf of Mexico shelf-edge banks. Dissertation, University of South Alabama

Gold JR, Saillant E (2007) Population structure of red snapper in the northern Gulf of Mexico. In: Patterson WF, Cowan JH Jr, Fitzhugh GR, Nieland DL (eds) Red Snapper ecology and fisheries in the US Gulf of Mexico. American fisheries society, symposium 60, Bethesda, Maryland, pp 201-216

Goodyear CP (1995) Red snapper in U.S. waters of the Gulf of Mexico. National Marine Fisheries Service, Southeast Fisheries Science Center, Miami Laboratory, Miami MIA95/96-05

Grabowski JH, Powers SP (2004) Habitat complexity mitigates trophic transfer on oyster reefs. Mar Ecol Prog Ser 277:291-295

Grossman GD, Jones GP, Seaman WJ Jr (1997) Do artificial reefs increase regional fish production? A review of existing data. Fisheries 22(4):17-27

Heifetz J, Dicosimo J, Gharrett AJ, Love MS, O’Connell VM, Stanley RD (eds) (2007) Biology, assessment, and management of North Pacific Rockfishes. Alaska Sea Grant College Program, Juneau

Hewitt DA, Hoenig JM (2005) Comparison of two approaches for estimating natural mortality based on longevity. Fish Bull US 103:433-437

Hilborn R (2006) Faith-based fisheries. Fisheries 32(11): 554-555

Hixon MA, Beets JP (1993) Predation, prey refugees, and the structure of coral-reef fish assemblages. Ecol Monogr 63:77-101

Hixon MA, Webster MS (2002) Chapter 14 density dependence in Reef fish populations. Coral Reef fishes, Elsevier Science, pp 303-323

Hoenig JM (1983) Empirical use of longevity data to estimate mortality rates. Fish Bull US 82:898-903

Holbrook SJ, Forrester GE, Schmitt RJ (2000) Spatial patterns in abundance of a damselfish reflect availability of suitable habitat. Oecologia 122:109-120

Hood PB, Strelcheck AJ, Steele P (2007) A history or red snapper management in the Gulf of Mexico. In: Patterson WF, Cowan JH Jr, Fitzhugh GR, Nieland DL (eds) Red Snapper ecology and fisheries in the US Gulf of Mexico. American fisheries society, symposium 60, Bethesda, Maryland, pp 267-284

Houde ED (1987) Fish early life dynamics and recruitment variability. Am Fish Soc Symp 2:17-29

Houde ED (1989a) Subtleties and episodes in the early life of fishes. J Fish Biol 35(Supplement A):29-38

Houde ED (1989b) Comparative growth, mortality, and energetics of marine fish larvae: temperature and implied latitudinal effects. Fish Bull US 87:471-495

Houde ED (1996) Evaluating stage-specific survival during the early life of fish. In: Watanabe Y, Yamashia Y, Oozcki Y (eds) Survival strategies in early life stages of marine resources. A.A. Balkema, Yokohama, pp 51-66

Houde ED (2008) Emerging from Hjort's Shadow. J Northwest Atl Fish Sci 4:53-70

Houde ED, Zastrow CE (1993) Ecosystem- and taxon-specific dynamic and energetics properties of larval fish assemblages. Bull Mar Sci 53:290-335

ICES (2009) Report of the working group on the ecosystem effects of fishing activities (WGECO), 15-21 April 2009, Copenhagen, Denmark. ICES CM 2009/ACOM:20, p 190

Jackson MW, Cowan JH Jr, Nieland DL (2007) Demographic differences in northern Gulf of Mexico red snapper: implications for the unit stock hypothesis. In: Patterson WF, Cowan JH Jr, Fitzhugh GR, Nieland DL (eds) Red Snapper ecology and fisheries in the US Gulf of Mexico. American fisheries society, symposium 60, Bethesda, Maryland, pp 217-228

Kennicutt MC, Schroeder WW, Brooks JM (1995) Temporal and spatial variations in sediment characteristics on the Mississippi-Alabama continental shelf. Cont Shelf Res $15: 1-18$

Kraak SBM (2007) Does the probabilistic maturation reaction norapproach disentangle phenotypic plasticity from genetic change? Mar Ecol Prog Ser 335:295-300

Law R (2007) Fisheries-induced evolution: present status and future directions. Mar Ecol Prog Ser 335:271-277

Lindberg WJ, Frazer TK, Stanton GR (1990) Population effects of refuge dispersion for adult stone crabs (Xanthidae, Menippe). Mar Ecol Prog Ser 66:239-349

Lindberg WJ, Frazer TK, Portier KM, Vose F, Loftin J, Murie DJ, Mason DM, Nagy B, Hart MK (2006) Densitydependent habitat selection and performance by a large mobile reef fish. Ecol Appl 16:731-746

Lorenzen K (1996) The relationship between body weight and natural mortality in juvenile and adult fish: a comparison of natural ecosystems and aquaculture. J Fish Biol 49: $627-642$

Lorenzen K (2000) Allometry of natural mortality as a basis for assessing optimal release size in fish stocking programmes. Can J Fish Aquat Sci 57:2374-2381

Lorenzen K, Enberg K (2002) Density-dependent growth as a key mechanism in the regulation of fish populations: evidence from among-population comparisons. Proc $\mathrm{R}$ Soc Lond 269:49-54

Love MS, Yoklavich M, Thorsteinson L (2005) The Rockfishes of the Northeast Pacific. Wiley, Hoboken

McCawley J, Cowan JH Jr (2007) Seasonal and size specific diet and prey demand of red snapper on Alabama artificial reefs: Implications for management. In: Patterson WF, Cowan JH Jr, Fitzhugh GR, Nieland DL (eds) Red Snapper Ecology and Fisheries in the US Gulf of Mexico. American Fisheries Society, symposium 60, Bethesda, Maryland, pp 77-104

McDonough M (2008) Oil platforms and red snapper movement. Thesis, Louisiana State University

Milicich MJ, Doherty PJ (1994) Larval supply of coral reef fish populations: magnitude and synchrony of replenishment to Lizard Island, Great Barrier Reef. Mar Ecol Prog Ser 110:121-134

Moe MA Jr (1963) A survey of offshore fishing in Florida. Professional Papers Series Number 4, Florida State Board 
of Conservation, Marine Laboratory, St. Petersburg, Florida

Murawski SA, Rago PJ, Trippel EA (2001) Impacts of demographic variation in spawning characteristics on reference points for fishery management. ICES Mar Sci Symp 58:1002-1014

Musick JA (1999) Life in the slow lane. American Fisheries Society, Bethesda

Myers RA (1995) Recruitment of marine fish: the relative roles of density-dependent and density-independent mortality in the egg, larval, and juvenile stages. Mar Ecol Prog Ser 128:305-310

Myers RA, Mertz G (1998) The limits of exploitation: a precautionary approach. Ecol Appl 8:S165-S169

Nelson RS, Manooch CS III (1982) Growth and mortality of red snappers in the west-central Atlantic Ocean and northern Gulf of Mexico. Trans Am Fish Soc 111: 465-475

Nieland DL, Wilson CA, Fischer AJ (2007) Declining size at age among red snapper in the northern Gulf of Mexico: recovery or collapse? In: Patterson WF, Cowan JH Jr, Fitzhugh GR, Nieland DL (eds) Red Snapper Ecology and Fisheries in the US Gulf of Mexico. American Fisheries Society, symposium 60, Bethesda, Maryland, pp 329-336

NOAA (2004) Status of bycatch reduction device (BRD) performance and research in the north-central and western Gulf of Mexico. SEDAR7-DW-38. NOAA Fisheries, Southeast Fisheries Science Center, Mississippi Laboratories, Pascagoula, p 50

Ouzts AC, Szedlmayer ST (2003) Diel feeding patterns of red snapper on artificial reefs in the North-Central Gulf of Mexico. Trans Am Fish Soc 132:1186-1193

Page HM, Dugan JE, Schroeder DM, Nishimoto MM, Love MS, Hoesterey JC (2007) Trophic links and condition of a temperate reef fish: comparisons among offshore oil platform and natural reef habitats. Mar Ecol Prog Ser 344:245-256

Patterson WF III (1999) Aspects of the population ecology of the red snapper Lutjanus campechanus in an artificial reef area off Alabama. Dissertation, University of South Alabama

Patterson WF III (2007) A review of movement in Gulf of Mexico red snapper: implications for population structure. In: Patterson WF, Cowan JH Jr, Fitzhugh GR, Nieland DL (eds) Red Snapper Ecology and Fisheries in the US Gulf of Mexico. American Fisheries Society, symposium 60, Bethesda, Maryland, pp 245-262

Patterson WF, Cowan JH Jr, Wilson CA, Shipp RL (2001) Age and growth of red snapper, Lutjanus campechanus, from an artificial reef area off Alabama in the northern Gulf of Mexico. Fish Bull US 99:617-627

Patterson WF, Wilson CA, Bentley SJ, Cowan JH Jr, Henwood T, Allen YC, Dufrene TA (2005) Delineating juvenile red snapper habitat on the northern Gulf of Mexico continental shelf. In: Barnes BW, Thomas JP (eds) Benthic habitats and the effects of fishing. Am Fish Soc Symp 41:277-288

Pitcher TJ, Seaman W (2000) Petrarch's Principle: how protected human-made reefs can help the reconstruction of fisheries and marine ecosystems. Fish Fish 1:73-81

Porch CE (2007) An assessment of the red snapper fishery in the U.S. Gulf of Mexico using a spatially-explicit age-structured model. In: Patterson WF, Cowan JH Jr, Fitzhugh GR, Nieland DL (eds) Red Snapper ecology and fisheries in the US Gulf of Mexico. American fisheries society, symposium 60, Bethesda, Maryland, pp 355-384

Porch CE, Turner SC, Schirripa MJ (2007) Reconstructing the commercial landings of red snapper in the Gulf of Mexico from 1872-1963. In: Patterson WF, Cowan JH Jr, Fitzhugh GR, Nieland DL (eds) Red Snapper Ecology and Fisheries in the US Gulf of Mexico. American Fisheries Society, symposium 60, Bethesda, Maryland, pp 337-354

Powers SP, Grabowski JH, Peterson CH, Lindberg WJ (2003) Estimating enhancement of fish production by offshore artificial reefs: uncertainty exhibited by divergent scenarios. Mar Ecol Prog Ser 264:265-277

Ramos J, Santos MN, Whitmarsh D, Monteiro CC (2007) Stakeholder perceptions regarding the environmental and socio-economic impacts of the Algarve artificial reefs. Hydrobiol 580:181-191

Render JH (1995) The life history (age, growth, and reproduction) of red snapper (Lutjanus campechanus) and its affinity for oil and gas platforms. Thesis, Louisiana State University

Ricker WE (1975) Computation and interpretation of biological statistics of fish populations. Bull Fish Res Board Can 191:1-382

Rijnsdorp AD (1993) Fisheries as a large-scale experiment on life-history evolution: disentangling phenotypic and genetic effects in changes in maturation and reproduction of North Sea plaice, Pleuronectes platessa L. Oecologia 96:391-401

Rooker JR, Landry AM, Geary BW, Harper JA (2004) Assessment of a shell bank and associated substrates as nursery habitat of post settlement red snapper. Estuar Coast Shelf Sci 59:653-661

Sale P (ed) (1991) The ecology of fishes on Coral Reefs. Academic Press, San Diego

Sale P (ed) (2002) Coral Reef Fishes: dynamics and diversity in a complex ecosystem. Academic Press, San Diego

Schroeder DM, Love MS (2002) Recreational fishing and marine fish populations. CalCOFI Rep 43:182-190

Schroeder WW, Shultz AW, Dindo JJ (1988) Innershelf hardbottom areas, northeastern Gulf of Mexico. Gulf Coast Assoc Geol Soc Trans 38:535-541

Schroepfer RL, Szedlmayer ST (2006) Estimates of residence and site fidelity for red snapper Lutjanus campechanus on artificial reefs in the northeastern Gulf of Mexico. Bull Mar Sci 78:93-102

SEDAR (2005) Southeast Data, Assessment, and Review: Stock Assessment Report of SEDAR 7: Gulf of Mexico Red Snapper. SEDAR7. One Southpark Circle \#306, Charleston, SC 29414

SEDAR (2009) Stock Assessment of Red Snapper in the Gulf of Mexico. SEDAR Assessment Update. Report of the Update Assessment Workshop, Miami, Florida, August 24-28, 2009, DRAFT 4.2 11/30/2009

Shepherd JG, Cushing DH (1980) A mechanism for densitydependent survival of larval fish as the basis of a stockrecruitment relationship. J Cons Int Explor Mer 39:160-167

Shipley B (2008) Red snapper Lutjanus campechanus food web models on Alabama artificial reefs. Dissertation, University of South Alabama 
Shipp RL (1999) The artificial reef debate: are we asking the wrong questions? Gulf Mex Sci 17:51-55

Shipp RL, Bortone SA (2009) A prospective of the importance of artificial habitat on the management of red snapper in the Gulf of Mexico. Rev Fish Sci 17:41-47

Stanley DR, Wilson CA (2003) Seasonal and spatial variation in the biomass and size frequency distribution of fish associated with oil and gas platforms in the northern Gulf of Mexico. In: Stanley DR, Scarborough-Bull A (eds) Fisheries, Reefs, and Offshore Development. American Fisheries Society, symposium 36, Bethesda, Maryland, pp 123-154

Strelcheck AJ, Cowan JH Jr, Shah A (2005) Influence of Reef Location on Artifical-Reef Fish Assemblages in the Northcentral Gulf of Mexico. Bull Mar Sci 77:425-440

Szedlmayer ST (2007) An evaluation of the benefits of artificial habitats for red snapper, Lutjanus campechanus, in the northeast Gulf of Mexico. Proc Gulf Caribb Fish Res Inst 59:633-641

Szedlmayer ST, Lee JD (2004) Diet shifts of juvenile red snapper (Lutjanus campechanus) with changes in habitat and fish size. Fish Bull US 102:366-375

Szedlmayer ST, Shipp RL (1994) Movement and growth of red snapper, Lutjanus campechanus, at artificial reef sites in the northeastern Gulf of Mexico. Bull Mar Sci 55:887-896

Trippel EA (1995) Age at maturity as a stress indicator in fisheries. Bioscience 45:759-771

Trippel EA, Kjesbu OS, Solemial P (1997) Effects of adult age and size structure on reproductive output in marine fishes. In: Chambers RC, Trippel EA (eds) Early life history and recruitment in fish populations. Chapman and Hall, London, pp 29-62

USGS (2008) Characterization of northern Gulf of Mexico deepwater hard bottom communities with emphasis of Lophelia coral-Lophelia reef megafaunal community structure, biotopes, genetics, microbial ecology and geology. In: Sulak KJ, Randall MT Luke KE, Norem AD, Miller JM (eds) USGS Open File Report 2008-1148; OCS Study MMS 2008-015, 15 April 2008, 8 Chapters, pp., 8 Master Appendices

Venturelli PA, Shuter BJ, Murphy CA (2009) Evidence for harvest-induced maternal influences on the reproductive rates of fish populations. Proc R Soc London B 276:919-924
VERSAR (2009) Review and synthesis of biological information for use in management decisions concerning decommissioning of offshore oil and gas structures in the Gulf of Mexico. Final Report Contract \# 1435-01-0539082, Minerals Management Service, United States Department of Interior

Walters CJ, Martell SJ (2004) Fisheries ecology and management. Princeton University Press, Princeton

Walters CJ, Hilborn R, Christensen V (2008a) Surplus production dynamics in declining and recovering fish populations. Can J Fish Aquat Sci 65:2536-2551

Walters CJ, Martell SJ, Christensen V, Mahmoudi B (2008b) An ECOSIM model for exploring Gulf of Mexico ecosystem management options: implications of including multistanza life history models for policy predictions. Bull Mar Sci 83:251-271

Watson J, Shah A, Nicholls S, Foster D (1997) Bycatch reduction estimates for selected species in the Gulf of Mexico for bycatch reduction devices evaluated under the regional bycatch program. National Marine Fisheries Service, Mississippi Laboratories, Pascagoula

Wells RJD, Cowan JH Jr, Fry B (2008a) Feeding ecology of red snapper, Lutjanus campechanus, in the northern Gulf of Mexico. Mar Ecol Prog Ser 361:213-225

Wells RJD, Cowan JH Jr, Patterson WF III, Walters CJ (2008b) Effect of trawling on juvenile red snapper (Lutjanus campechanus) habitat selection and life history parameters. Can J Fish Aquat Sci 65:2399-2411

Westmeyer MP, Wilson CA, Nieland DL (2007) Fidelity of red snapper to petroleum platforms in the northern Gulf of Mexico. In: Patterson WF, Cowan JH Jr, Fitzhugh GR, Nieland DL (eds) Red Snapper Ecology and Fisheries in the US Gulf of Mexico. American Fisheries Society, symposium 60, Bethesda, Maryland, pp 105-122

Wilson CA, Nieland DL (2001) Age and growth of red snapper, Lutjanus campechanus, from the northern Gulf of Mexico off Louisiana. Fish Bull US 99:653-664

Winemiller KO, Rose KA (1992) Patterns of life-history diversification in North American fishes: implications for population regulation. Can J Fish Aquat Sci 49:21962220

Winemiller KO, Rose KA (1993) Why do most fish produce so many tiny offspring? Am Nat 142:585-603 